\title{
Exploring Common Expectations from Students in Large Multilevel Secondary Level English Classes
}

\author{
Ashok Raj Khati
}

\section{Abstract}

English has been used in diverse contexts around the globe. Teaching English in large multilevel classes is one of the major challenges in ELT setting. The majority of classrooms consist of multilevel groups where students have different needs and learning styles. This type of heterogeneity may enrich the variety of social interaction, more life experiences and knowledge, more opinions, interests and ideas but it also creates situations that challenge teachers' resourcefulness while trying to give each student an opportunity to learn English language. The situation is more challenging in under-resourced situations of Nepal. Moreover, in this type of classes teacher may not be familiar with different needs and prospects of students. Thus, this study attempts to find out the very common expectations of students in a large English class where students have different levels.

Key words: Large class, multilevel, heterogeneous, homogeneous, mixed ability classes

\section{Introduction}

"Large is of course a relative term and what a "large class' is will vary place to place” (Ur, 2005, p. 19). She further states that a 'heterogeneous' class is one that has different kinds of learners in it, as opposed to a 'homogeneous' class, where the learners are similar. Thus, a large class has many students and a multilevel class has students of different levels. There are many learners' differences in this type of classes such as differences on language learning ability, their cultural background, learning style, age, attitude to the language, mother tongue, learning experience, motivational orientation, etc. In a nutshell, a large multilevel class has many students including those who communicate in English at a variety of different levels.

No two humans are the same in the world as human beings have multiple intelligences. Thus there is no point in teaching everybody in the same way; instead learners should be helped to become independent and creative while using their second language. There is no such thing as a 'homogeneous' class. By nature, large classes are heterogeneous.

Teachers working in our context have encountered many problems in this type of classroom such as excessive 'check' work (homework/class work), low interaction between teachers and students, difficult classroom organization, difficulty in determining the individual needs of each student, very low or uneven participation of students in various activities, difficult to ensure that all students are challenged, disciplinary problems, low interest levels, different learning styles, excessive use of mother tongue, etc. Furthermore, there are always high achievers who communicate in English and participate; consequently, many teachers may not understand the learning prospects of low achievers in these classes.

At the same time, there are more comments, more personal experiences, more opinions and ideas shared in large multilevel classes and these 
classes provide more chances to enhance mutual learning (forming cross-ability groups). The large multilevel classroom itself is an opportunity for interaction moreover; it increases the knowledge of others, and their values and personalities. Thus, large multilevel classroom could be a greater opportunity for creativity.

\section{The Study}

The present study aims to find out the very common expectations of students inside the classroom where students are learning English at a variety of different pace and the classroom is large in size. The study is mainly focused on six different areas: classroom management, establishing collaboration, range of tasks, giving feedback, classroom English and home assignment. For the questionnaire survey, sixty students of tenth grade from government-aided school were selected to get required information. Thirty students were from Ramechhap district and thirty from Kathmandu valley representing rural and urban area of Nepal respectably. Two schools: Manthali higher secondary school Manthali, Ramechhap and Gyanodaya sechodary school Bafal, Kathmandu were selected for the survey purpose. Both schools have more than 150 students in grade ten with three sections and thirty students were selected according to their roll number at the regular interval of five. The population was sampled using purposive non-random sampling procedure. To collect primary data, one structured questionnaire was developed containing nineteen closed ended questions. Students were asked to tick the both nominal and ordinal alternatives.

\section{Results}

The data is presented in tables followed by discussion. Each theme of research question deserves one table and discussion as follows:

\section{Classroom management}

In the tables, numerical value ' 0 ' refers to the zero expectation (they do not expect at all) and ' 1 ' to the least like expectation of students. Similarly, '2' refers to the normal or average expectation and ' 3 ' indicates the top (most liked) expectation.

The researcher inquired about classroom management that plays vital role in a large multilevel class by raising four questions. The study shows that fifty percent students have

Table 1: Classroom Management

\begin{tabular}{|c|c|c|c|c|c|}
\hline Questions & Options & $\begin{array}{l}\text { Responses } \\
\text { (Urban-30) }\end{array}$ & $\begin{array}{l}\text { Respons- } \\
\text { es (ru- } \\
\text { ral-30) }\end{array}$ & $\begin{array}{c}\text { Total re- } \\
\text { sponses } \\
(60)\end{array}$ & $\begin{array}{l}\text { Overall (\%) } \\
\text { Percentage } \\
\text { (Total-60) }\end{array}$ \\
\hline $\begin{array}{l}\text { 1. To what extent do you } \\
\text { like the } \\
\text { fixed rules for your class } \\
\text { from } \\
\text { the very beginning of the } \\
\text { year? }\end{array}$ & 1 & $\begin{array}{ll}0- & 1 \\
1- & 2 \\
2- & 16 \\
3- & 11\end{array}$ & $\begin{array}{l}0-2 \\
2-9 \\
3-19\end{array}$ & $\begin{array}{ll}0-3 \\
1- & 2 \\
2- & 25 \\
3- & 30\end{array}$ & $\begin{array}{ll}0- & 5.00 \\
1- & 3.33 \\
2- & 41.67 \\
3- & 50.00\end{array}$ \\
\hline $\begin{array}{l}\text { 2. To what extent do you } \\
\text { like to } \\
\text { be called }\end{array}$ & $\begin{array}{l}\text { a. by your first name? } \\
\left.\begin{array}{llll}(0 & 1 & 2 & 3\end{array}\right) \\
\text { b. simply by 'you', ' he' or } \\
\begin{array}{llll}\text { 'she'? } \\
\left.\begin{array}{llll}(0 & 1 & 2 & 3\end{array}\right)\end{array}\end{array}$ & $\begin{array}{ll}a, 2- & 2 \\
a, 3- & 28\end{array}$ & $\begin{array}{l}a, 1-1 \\
a, 2-2 \\
a, 3-27\end{array}$ & $\begin{array}{l}a, 1-1 \\
a, 2-4 \\
a, 3-55\end{array}$ & $\begin{array}{ll}a, 1- & 1.66 \\
a, 2- & 6.67 \\
a, 3- & 91.67\end{array}$ \\
\hline $\begin{array}{l}\text { 3. To what extent do you } \\
\text { enjoy }\end{array}$ & $\begin{array}{l}\text { a. orderly rows (straight rows)? } \\
\left.\begin{array}{llll}(0 & 1 & 2 & 3\end{array}\right) \\
\text { b. round seating arrangement } \\
\text { (Circles)? } \\
\left.\begin{array}{llll}(0 & 1 & 2 & 3\end{array}\right)\end{array}$ & $\begin{array}{ll}a, 1- & 1 \\
a, 2- & 13 \\
a, 3- & 9 \\
b, 2- & 1 \\
b, 3- & 6 \\
\end{array}$ & $\begin{array}{l}a, 2-4 \\
a, 3-13 \\
b, 2-1 \\
b, 3-12\end{array}$ & $\begin{array}{l}a, 1-1 \\
a, 2-17 \\
a, 3-22 \\
b, 2-2 \\
b, 3-18\end{array}$ & $\begin{array}{ll}a, 1- & 1.67 \\
a, 2- & 28.33 \\
a, 3- & 36.67 \\
b, 2- & 3.33 \\
b, 3- & 30.00 \\
\end{array}$ \\
\hline $\begin{array}{l}\text { 4. To what extent do you } \\
\text { expect } \\
\text { your English teacher }\end{array}$ & $\begin{array}{l}\text { a. moving all around the class } \\
\text { to reach to you? } \\
\left.\begin{array}{llll}(0 & 1 & 2 & 3\end{array}\right) \\
\text { b. standing at the front so that } \\
\text { she/he could see all at once? } \\
\left.\begin{array}{llll}(0 & 1 & 2 & 3\end{array}\right)\end{array}$ & $\begin{array}{l}a, 0-1 \\
a, 2-3 \\
a, 3-24 \\
b, 3-2\end{array}$ & $\begin{array}{l}a, 2-2 \\
a, 3-27 \\
b, 2-1\end{array}$ & $\begin{array}{l}a, 0-1 \\
a, 2-5 \\
a, 3-51 \\
b, 2-1 \\
b, 3-2\end{array}$ & $\begin{array}{ll}a, 0- & 1.67 \\
a, 2- & 8.33 \\
a, 3- & 85.00 \\
b, 2- & 1.67 \\
b, 3- & 3.33\end{array}$ \\
\hline
\end{tabular}


the top expectations of fixed class rules from the very beginning of the academic year and more than forty percent students show their normal expectation. Thus, it is essential to establish class rules or routines from the very beginning. However, students often test the rules. Teacher should not make the mistake of reinterpreting the rules to reflect sympathy. He or she must be fair with all. Harmer (2008) states that the daily management of a large class will be greatly enhanced if we establish routines that we and our students recognize straightaway. He further opines this will make jobs like taking the register, setting and collecting homework, getting into pairs and groups, etc. far easier. At the same time, more than ninety percent students like to be called by their first names. Students will respond positively if they believe a teacher is genuinely interested in them. One of the ways to build respectful relationship with students is to learn names as quickly as possible. Names can be learned by:

- Association- we can look students and see if something strikes us. For example, Alice wears a blue hat.

- Visual connection- We can see students and notice their faces, body posture. For example, John is the tallest one.
- Aural connection- we can listen to the students' voice. For example, Diane speaks very politely.

So far as physical setting is concerned, more than sixty percent students are positive with orderly rows. However, considerable numbers of students $(30 \%)$ have shown their interest in circles. If possible, one can manage the seats on such a way that he or she can conduct group works. However, at the same time straight rows are also helpful to maintain direct eye contact that a teacher can observe the activities of all students. The study also shows that around ninety percent students expect their English teacher moving all around the class.

\section{Enhancing Collaboration}

The table 2 summarizes the responses under the theme of enhancing collaboration.

If we promote collaboration in this type of classroom, it will be beneficial. However, not all the students seem to work with their friends. Some students are found more frank and sociable than others who like group work and they are good at speaking. "Teacher can multiply the opportunities for practice and for creative language use by introducing pair and group work" (Cross, 1992). In this study, around fifty-five percent students

Table 2: Enhancing Collaboration

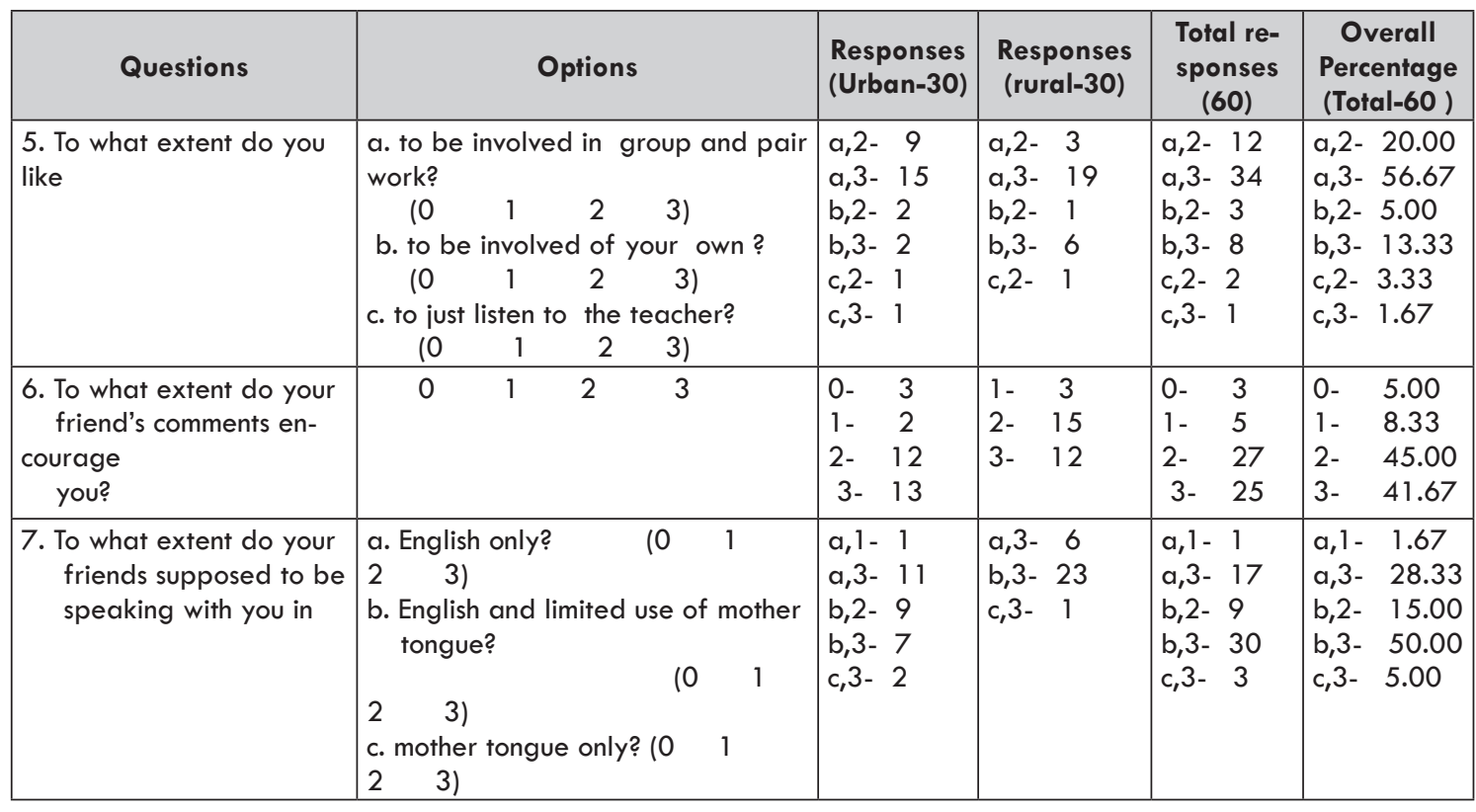


replied that they have enjoyed the group and pair work very much and twenty percent students have normally liked group and pair activities. However, eighteen percent students want to be involved of their own. Around eighty percent students seem to be positive with their friends' comments. The result indicates that a teacher can enhance collaborative activities. S/he can get learners to work cooperatively as s/he cannot directly interact with every individual himself or herself to maximize students' participation. Nevertheless, thirteen percent students have not found their friends' comments encouraging. May be they are introvert in nature. More than sixty percent students admitted that they like

Table: 3 Range of Tasks

\begin{tabular}{|c|c|c|c|c|c|c|}
\hline Questions & Options & & $\begin{array}{l}\text { Responses } \\
\text { (Urban-30) }\end{array}$ & $\begin{array}{c}\text { Responses } \\
\text { (rural-30) }\end{array}$ & $\begin{array}{l}\text { Total re- } \\
\text { sponses } \\
(60)\end{array}$ & $\begin{array}{c}\text { Overall } \\
\text { Percentage } \\
\text { (Total-60) }\end{array}$ \\
\hline $\begin{array}{l}\text { 8. To what extent do you } \\
\text { like to be } \\
\text { involved in/of }\end{array}$ & 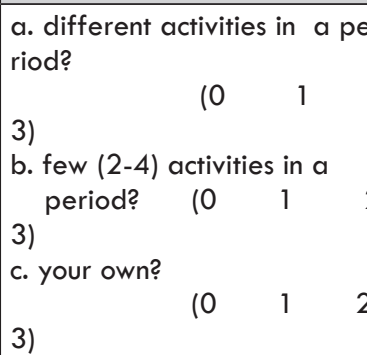 & 2 & $\begin{array}{ll}a, 2- & 2 \\
a, 3- & 4 \\
b, 1- & 1 \\
b, 2- & 14 \\
b, 3- & 8 \\
c, 2- & 1\end{array}$ & \begin{tabular}{|cc}
$a, 2-$ & 1 \\
$a, 3-$ & 9 \\
$b, 2-$ & 2 \\
$b, 3-$ & 13 \\
$c, 3-$ & 5
\end{tabular} & $\begin{array}{ll}a, 2- & 3 \\
a, 3- & 13 \\
b, 1- & 1 \\
b, 2- & 16 \\
b, 3- & 21 \\
c, 2- & 1 \\
c, 3- & 5\end{array}$ & $\begin{array}{ll}a, 2- & 5.00 \\
a, 3- & 21.66 \\
b, 1- & 1.67 \\
b, 2- & 26.67 \\
b, 3- & 35.00 \\
c, 2- & 1.67 \\
c, 3- & 8.33\end{array}$ \\
\hline $\begin{array}{l}\text { 9. What type of activities } \\
\text { do you } \\
\text { like? } \\
\text { (tick at least two) }\end{array}$ & $\begin{array}{l}\text { a. Language games } \\
\text { b- Language songs } \\
\text { c- Various contests } \\
\text { d- Sharing experiences } \\
\text { e- Project work } \\
\text { f- Telling jokes } \\
\text { g- Telling stories } \\
\text { h- Any other...... }\end{array}$ & & $\begin{array}{ll}\text { a- } & 8 \\
\text { b- } & 5 \\
\text { c- } & 9 \\
\text { d- } & 17 \\
\text { e- } & 10 \\
\text { f- } & 5 \\
\text { g- } & 6\end{array}$ & $\begin{array}{lc}\mathrm{a}- & 8 \\
\mathrm{~b}- & 12 \\
\mathrm{c}- & 14 \\
\mathrm{~d}- & 8 \\
\mathrm{e}- & 5 \\
\mathrm{f}- & 7 \\
\mathrm{~g}- & 6\end{array}$ & $\begin{array}{ll}\text { a- } & 16 \\
\text { b- } & 17 \\
\text { c- } & 23 \\
\text { d- } & 25 \\
\text { e- } & 15 \\
\text { f- } & 12 \\
\text { g- } & 12\end{array}$ & $\begin{array}{lc}\text { a- } & 26.67 \\
\text { b- } & 28.33 \\
\text { c- } & 38.33 \\
\text { d- } & 41.67 \\
\text { e- } & 25.00 \\
\text { f- } & 20.00 \\
\text { g- } & 20.00 \\
\text { (\% is taken } \\
\text { per option } \\
\text { separately) }\end{array}$ \\
\hline $\begin{array}{l}\text { 10. Which activities or } \\
\text { exercises are } \\
\text { encouraging for you? }\end{array}$ & $\begin{array}{l}\text { a. Very difficult } \\
\text { b. Challenging } \\
\text { c. Easy } \\
\text { d. Very easy }\end{array}$ & & $\begin{array}{ll}\text { b- } & 27 \\
\text { c- } & 3\end{array}$ & \begin{tabular}{|cc} 
a- & 2 \\
b- & 20 \\
c- & 7 \\
d- & 1 \\
\end{tabular} & $\begin{array}{lc}\text { a- } & 2 \\
\text { b- } & 47 \\
c- & 10 \\
\text { d- } & 1\end{array}$ & $\begin{array}{ll}\text { a- } & 3.33 \\
b- & 78.33 \\
c- & 16.67 \\
d- & 1.67\end{array}$ \\
\hline 11. Do you & $\begin{array}{l}\text { a. just like to complete the } \\
\text { activities given in the text- } \\
\text { book? } \\
\text { b. expect additional activitie } \\
\text { (more than of textbook) }\end{array}$ & & $\begin{array}{lc}a- & 2 \\
b- & 28\end{array}$ & \begin{tabular}{|lc}
$a-$ & 2 \\
b- & 28
\end{tabular} & $\begin{array}{ll}\text { a- } & 4 \\
\text { b- } & 56\end{array}$ & $\begin{array}{ll}\text { a- } & 6.67 \\
b- & 93.33\end{array}$ \\
\hline $\begin{array}{l}\text { 12. To what extent do you } \\
\text { Suppose } \\
\text { your English teacher } \\
\text { encourage } \\
\text { your various/all re- } \\
\text { sponses? }\end{array}$ & 0 & 3 & $\begin{array}{ll}0- & 2 \\
1- & 1 \\
2- & 21 \\
3- & 6\end{array}$ & $\begin{array}{ll}0- & 1 \\
1- & 2 \\
2- & 12 \\
3- & 15\end{array}$ & $\begin{array}{ll}0- & 3 \\
1- & 3 \\
2- & 33 \\
3- & 21\end{array}$ & $\begin{array}{ll}0- & 5.00 \\
1- & 5.00 \\
2- & 55.00 \\
3- & 35.00\end{array}$ \\
\hline
\end{tabular}

Journal of NELTA Vol. 15 No.1-2 December 2010 their friends talking in English with limited use of mother tongue in English period whereas thirty percent students in class think that they are supposed to be speaking with their friends in English only. It proves that limited use of mother tongue along with English facilitates cooperation and collaborative activities.

\section{Range of Tasks}

I have summarized the responses in the table 3 regarding the range of classroom tasks for language learning.

The study confirms that more than twenty-five percent students have expected different activities in a period. It shows that they generally enjoy the lesson mixed with various techniques and 
activities. Dewan (2003) admits that a teacher has to accommodate variety in teaching techniques for different levels in the class so that those who do not like one phase of an activity or topic may like the next. But the study demonstrates that around fifty percent learners seem to be interested in a few activities in a period and five percent students do not show their concern in various activities. The result indicates that every student has his or her own interests and learning styles, which necessitates the teacher creating variety in a lesson because one activity may not be suitable for all. Among various activities, forty percent students have chosen the activity 'sharing experiences' in English language learning. Thirtyeight percent students have expected contests like activities in English period and students have shown their normal expectations in activities like language songs, games, project work, telling jokes and stories. More than seventy percent students responded that they like the challenging activities in learning English, neither too easy nor too difficult. It indicates that teacher should create the right level of challenge in learning English. Sixteen percent students show their interest in easy exercises. The result also confirms that ninety-three percent students expect additional activities more than of textbook. This also points to the fact that teacher should break the monotony of textbook. Similarly, ninety percent students suppose their English teacher encourage their various responses. In this case, a teacher can use open-ended questions to invite students in discussion since these questions provide opportunities for responses at various levels. The data gives clear direction to a teacher that $\mathrm{s} / \mathrm{he}$ should make best effort to provide different tasks for different levels.

\section{Classroom English}

Table 4 gives a brief overview of student responses on classroom English.

Successful classroom communication of language learning takes place only when teachers use appropriate language structures during different classroom procedures (Bhatta, 1998). There is no doubt that classroom English has a key role in the large multilevel classes. Here in this study, only twenty percent students admitted that their English teacher should speak in English only. On the other hand, more than seventy-five percent students replied that their teacher should use English with restricted use of mother tongue. Nevertheless, the data also reveals the fact that sixty-one percent students have preferred a teacher who introduces new words in every day English. At the same time, considerable numbers of students have shown their expectation to the simpler English with short expressions. Thirty-one percent students have expected native like English from their teacher. The result points toward the use of simpler English with shorter expressions, introducing some new words each day rather than using longer and complex sentences.

Table: 4 Classroom English

\begin{tabular}{|c|c|c|c|c|c|}
\hline Questions & Options & $\begin{array}{l}\text { Responses } \\
\text { (Urban 30) }\end{array}$ & $\begin{array}{c}\text { Responses } \\
\text { (rural-30) }\end{array}$ & $\begin{array}{c}\text { Total re- } \\
\text { sponses } \\
(60)\end{array}$ & $\begin{array}{c}\text { Overall } \\
\text { Percentage } \\
\text { (Total-60) }\end{array}$ \\
\hline $\begin{array}{l}\text { 13. Do you like your teacher } \\
\text { speaking in }\end{array}$ & $\begin{array}{l}\text { a. English only? } \\
\text { b. English with limited use } \\
\text { of mother tongue? } \\
\text { c- Mother tongue only? }\end{array}$ & $\begin{array}{ll}a- & 8 \\
b- & 20 \\
c- & 2\end{array}$ & $\begin{array}{l}a-4 \\
b-26\end{array}$ & $\begin{array}{l}a-12 \\
b-46 \\
c-2\end{array}$ & $\begin{array}{ll}a- & 20.00 \\
b- & 76.67 \\
c- & 3.33\end{array}$ \\
\hline $\begin{array}{l}\text { 14. What type of classroom } \\
\text { English } \\
\text { do you expect from your } \\
\text { teacher? } \\
\text { (Choose at least } \\
\text { two) }\end{array}$ & $\begin{array}{l}\text { a. English with longer } \\
\text { sentences } \\
\text { b. English with introducing } \\
\text { new words } \\
\text { c. Simpler English } \\
\text { d. Native like English } \\
\text { e. Shorter expressions } \\
\text { f. Any other (mention) }\end{array}$ & $\begin{array}{lc}\text { b- } & 26 \\
c- & 11 \\
d- & 13 \\
\text { e- } & 10\end{array}$ & $\begin{array}{ll}a- & 2 \\
b- & 11 \\
c- & 17 \\
\text { d- } & 6 \\
\text { e- } & 23\end{array}$ & $\begin{array}{l}\text { a- } 2 \\
\text { b- } 37 \\
\text { c- } 28 \\
\text { d- } 19 \\
\text { e- } 33\end{array}$ & $\begin{array}{ll}a- & 3.33 \\
b- & 61.67 \\
c- & 46.67 \\
d- & 31.67 \\
\text { e- } & 55.00 \\
f- & \\
\text { (\% is taken } \\
\text { per option } \\
\text { separately) }\end{array}$ \\
\hline
\end{tabular}


Table: 5 Feedback

\begin{tabular}{|c|c|c|c|c|c|c|}
\hline Questions & \multicolumn{2}{|c|}{ Options } & $\begin{array}{l}\text { Responses } \\
\text { (Urban-30) }\end{array}$ & $\begin{array}{c}\text { Responses } \\
\text { (rural-30) }\end{array}$ & $\begin{array}{c}\text { Total re- } \\
\text { sponses } \\
(60)\end{array}$ & $\begin{array}{c}\text { Overall } \\
\text { Percentage } \\
\text { (Total-60) }\end{array}$ \\
\hline $\begin{array}{l}\text { 15. To what extent do you } \\
\text { like to be informed } \\
\text { about you progress } \\
\text { by your teacher? }\end{array}$ & 1 & 2 & $\begin{array}{ll}0- & 2 \\
2- & 14 \\
3- & 14\end{array}$ & $\begin{array}{ll}1-1 \\
2- & 10 \\
3- & 19\end{array}$ & \begin{tabular}{|ll}
$0-$ & 2 \\
$1-$ & 1 \\
$2-$ & 24 \\
$3-$ & 33 \\
\end{tabular} & 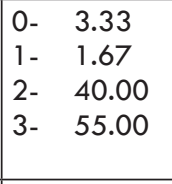 \\
\hline $\begin{array}{l}\text { 16. How do you like to be } \\
\text { informed? }\end{array}$ & $\begin{array}{l}\text { a. Teache } \\
\text { your } n \\
\text { b. Person } \\
\text { classro } \\
\text { c. gettins } \\
\text { room } \\
\text { d. In conf } \\
\text { e. Any of }\end{array}$ & $\begin{array}{l}\text { ' comments on } \\
\text { ebook } \\
\text { meeting outside } \\
\text { n } \\
\text { o you inside class- } \\
\text { ence } \\
\text { r............ }\end{array}$ & $\begin{array}{lc}\text { a- } & 4 \\
\text { b- } & 11 \\
c- & 13 \\
\text { d- } & 2\end{array}$ & $\begin{array}{l}\text { a- } 7 \\
\text { b- } 4 \\
\text { c- } 19\end{array}$ & $\begin{array}{ll}a- & 11 \\
b- & 15 \\
c- & 32 \\
d- & 2\end{array}$ & $\begin{array}{ll}\text { a- } & 18.33 \\
\text { b- } & 25.00 \\
\text { c- } & 53.34 \\
\text { d- } & 3.33\end{array}$ \\
\hline
\end{tabular}

\section{Feedback}

Students had varied responses on nature and frequency of feedback. (See Table 5 as given above)

One of the great challenges of teaching in a large class is trying to communicate with students at the personal level. That is why it is really difficult in getting and giving feedback. Ninety-five percent students reported that they like to be informed about their progress by their teacher. But majority of them (more than fifty percent) expect their teacher getting to the students inside classroom while giving feedback. Similarly, twenty-five percent students replied that they enjoy personal meeting with teacher outside classroom and eighteen percent students have expected the teachers' comments on their notebook to receive feedback.

\section{Home Assignments}

I summarize the students' responses on nature and frequency of feedback they expect from their teachers. (See Table 6)

Correcting written assignment is time consuming in a large class. When asked the students about the checking home tasks, seventy-five percent students viewed that their home assignment should be checked every day. In this research data, eight percent students replied that they like their assignment checked once a week. Khati (2010) stated that ten to fifteen percent students often neglect assignments particularly class works simply because they think they can bypass in a large class unless a teacher gives special attention to them. Sixteen percent students reported that they like their home assignments checked twice or thrice a week. At the same time, more than seventy-five percent students stated that they like their written tasks corrected by their teacher. Very few students seem to have enjoyed peer and selfcorrection. But in the process of data collection, researcher found out that a few students seemed to be familiar with peer and self correction. Very interestingly, majority of students responded that they expect extra home tasks more than of compulsory tasks. For example, a teacher gives the 'fill in the gap' exercise containing ten items as home tasks for all students but there are some students who are often high achievers expect more than this. It gives clear direction to the teachers that they should give different tasks to different students to manage mixed abilities in a class. Harmer (2008) suggests that we might ask all students to look at the same reading text but make a difference in terms of the tasks we ask them to do in response to that text.

The study does not show huge variation between the expectations of students of urban and rural areas. The students from rural area show slightly higher expectation in using mother tongue in an English class, whereas the sharing experiences like activities is more liked by the students from urban area. Similarly, the students from urban seem to be more frank and shared as they have higher expectation in participating group and pair 
Table: 6 Home assignments

\begin{tabular}{|c|c|c|c|c|c|}
\hline Questions & Options & $\begin{array}{l}\text { Responses } \\
\text { (Urban-30) }\end{array}$ & $\begin{array}{c}\text { Responses } \\
\text { (rural-30) }\end{array}$ & $\begin{array}{l}\text { Total re- } \\
\text { sponses } \\
(60)\end{array}$ & $\begin{array}{c}\text { Overall } \\
\text { Percentage } \\
\text { (Total-60) }\end{array}$ \\
\hline $\begin{array}{l}\text { 17. Do you expect your } \\
\text { homework checked }\end{array}$ & $\begin{array}{l}\text { a. Every day? } \\
\text { b. Twice or thrice a week? } \\
\text { c. Once a week? }\end{array}$ & $\begin{array}{l}a-19 \\
b-6 \\
c-5\end{array}$ & $\begin{array}{l}a-26 \\
b-4\end{array}$ & $\begin{array}{l}a-45 \\
b-10 \\
c-5\end{array}$ & $\begin{array}{ll}a- & 75.00 \\
b- & 16.67 \\
c- & 8.33\end{array}$ \\
\hline $\begin{array}{l}\text { 18. How do you enjoy } \\
\text { your written tasks to be } \\
\text { checked? }\end{array}$ & $\begin{array}{l}\text { a. By your teacher } \\
\text { b. By your peer } \\
\text { c. By yourself (self correc- } \\
\text { tion) }\end{array}$ & $\begin{array}{ll}a- & 18 \\
b- & 6 \\
c- & 6\end{array}$ & $\begin{array}{l}a-28 \\
b-1 \\
c-1\end{array}$ & $\begin{array}{l}a-56 \\
b-7 \\
c-7\end{array}$ & $\begin{array}{ll}a- & 76.67 \\
b- & 11.67 \\
c- & 11.66\end{array}$ \\
\hline $\begin{array}{l}\text { 19. Do you expect extra } \\
\text { home Tasks? (more of } \\
\text { compulsory tasks) }\end{array}$ & $\begin{array}{l}\text { a. Yes } \\
\text { b. No }\end{array}$ & $\begin{array}{l}a-14 \\
b-16\end{array}$ & $\begin{array}{l}a-18 \\
b-12\end{array}$ & $\begin{array}{l}a-32 \\
b-28\end{array}$ & $\begin{array}{l}\text { a- } 53.33 \\
\text { b- } 46.67\end{array}$ \\
\hline
\end{tabular}

tasks, and they have three times more expectation of native like English than the students of rural area who expect more simple English. Very few number of students from rural area seem to have liked personal meeting with the teacher outside classroom. The study also shows that peer and self-correction of assignment had been rarely practiced in rural areas.

\section{Conclusion}

The study reveals many findings at a time regarding the expectations of students in large multilevel classes. Many teachers do not seem to make trouble to learn names of the students but in this study, more than ninety percent students reported that they like to be called by their first names. Upadhaya (2000) points out that learning names of students and using them establishes an atmosphere of mutual interest and responsibility. She further opines about the movement of the teacher that moving around the class also makes the class seem smaller and encourages student involvement. This study also proves that an English teacher should move all around the class. Some teachers often find giving lectures easier and more comfortable than organizing group work and pair work in spite of the students' interest in these activities. Sharing experiences like activity is highly preferred by the considerable (40\%) number of students. It shows that sharing experiences of teachers and students has strong motivational drive on the part of students. In the process of data collection, for example, they seemed to be interested in the passage (appendix 1) of $10^{\text {th }}$ grade English (CDC, 2010 p. 104) in which the narrator is telling his story when he got the first pair of trousers. In the data, more than ninety percent students reported that they expect additional activities more than of textbook. It is clearly revealed that students might have felt boring with the limited and repetitive exercises, materials and techniques used in the prescribed textbook. This study also supports that limited use of mother tongue in English classroom is bearable and accepted. However, while using English, the teacher should introduce some new words every day in simpler and shorter expression. In case of feedback, feedback at personal level inside classroom is more preferable. But William and Burden (1997) recommends for feedback that is informational. The study also reveals that most of the students like challenging activities, neither too easy, nor too difficult. It is commonly believed that excessive 'check' work cannot be managed in large multilevel classes. But the same home assignment to all may be demotivated because of the different levels of students. The same activity may be too easy for some students may not be for others. Thus, it is essential to provide different tasks to different students to grow them at their own pace. Students have their own unique learning prospects in English. Therefore, in a large heterogeneous class, there is no alternative of developing a collaborative working atmosphere, providing a variety of works and making all students involved in various activities appropriate for different levels. 
Ashok Raj Khati has been associated with English language teaching for a decade. He teaches the course on English Language Teaching Methods at Gauri Shankar multiple campus, Ramechhap affiliated with Tribhuvan University Nepal. Mr. Khati has presented papers in seminars and conferences, and published a few articles in various journals. His areas of interests include the psychology in language teaching, teacher education and English language pedagogy. As a paper presenter, he has travelled throughout the country. He leads one of the NELTA branches in the capacity of the chair at present in mid-eastern part of Nepal based in Ramechhap district.

\section{References}

Bhatta, C. P. (1998). Classroom English for teachers. Kathmandu: CERD Nepal.

Cross, D. (1992). A Practical handbook of language teaching. London: Prentice Hall.

Curriculum Development Centre (CDC) Nepal. (2010). Grade 10 English. Sanothimi: CDC.
Dewan, S. (2003). Teaching large multilevel classes. Journal of NELTA, 8, (1) 158-162.

Harmer, J. (2008). The practice of English language teaching. Longman: Pearson Longman.

Khati, A.R. (2010). Enhancing communication in large multilevel classes. A paper presented at the $15^{\text {th }}$ international conference of NELTA, Nepal.

Upadhaya, M. (2000). Teaching English in large classes. Journal of NELTA, 5 (2) 67-70

Ur, P. (2005). A course in language teaching: theory and practice. Cambridge: CUP.

William, M. \& Burden, R. L. (1997). Psychology for language teachers: A social constructivist approach. London: CUP.

\section{Appendix}

My parents did not believe in boys wearing trousers, so I wore shorts to school. I wanted to wear trousers, but every time I opened my mouth my parents told me to shut up.

One day, the class teachers told us that we were going to have a group photograph taken and he asked us to wear trousers for the occasion. I was in a dilemma as I did not possess a pair of trousers.

After school, I asked some of my friends to lend me a pair of trousers, but no one had a pair which would fit me. I even tried on a pair of my father's trousers. They were too short for me and much too large at the waist. I gave up in despair.

The next day arrived. I thought of not going to school but my parents told me to get ready. They told me to stop grumbling because there was nothing wrong in wearing shorts. So I turned up as usual at school. The class teacher was aghast when he saw me. He and some other students wanted me to be excluded from the photograph but the head teacher intervened. She asked me to join the group. The class teacher told me to sit in the front with two students on either side of me.

The photograph was duly taken. A few days later a copy of the picture appeared on the noticeboard. Crowds of students gathered to see it. It was a well-taken photograph. All the students were there in their well-ironed, spotlessly white shirts and trousers expect me in the front row, with my kobbly knees conspicuously exposed! You can imagine how I felt!

But the incident had a happy ending. I bought a copy of the photograph and showed it to my parents. My father immediately asked my mother to buy some white trousers for me - my very first pair. 